\title{
Simultaneous Determination of Genomic DNA Methylation and Uracil Misincorporation
}

\author{
Abalo Chango $^{a, b}$ Afif M. Abdel Nour ${ }^{a}$ Celine Niquet ${ }^{c}$ Frederic J. Tessier ${ }^{c}$ \\ a Unit EGEAL and Laboratory of Nutritional Genomics, Institut Polytechnique LaSalle Beauvais, Agrohealth, \\ ${ }^{b}$ INSERM U724, and 'Platform of Analytical Chemistry, Beauvais, France
}

\author{
Key Words \\ Cancer $\cdot$ Chromatography $\cdot$ DNA methylation $\cdot$ Folate $\cdot$ \\ Cytosine $\cdot$ Uracil
}

\begin{abstract}
Objective: To develop a method for the simultaneous measurement of 5-methylcytosine (5-metC) and 2'-deoxyuridine monophosphate (dU). Materials and Methods: Genomic DNA was extracted from the HepG2 cell line grown in experimental complete medium or in folate-depleted medium. Samples were treated with RNAse A and RNAse T1 to avoid any RNA contamination. High-performance liquid chromatography (HPLC)/electrospray ionization mass spectrometric (ESI-MS) method was used to separate nucleotides after enzymatic hydrolysis of DNA with nuclease P1, phosphodiesterase I and alkaline phosphatase. Results: Using this sensitive new methodology, we were able to quantify simultaneously the concentration of DNA-5-metC and DNAuracil in DNA. The linear correlation coefficient $\left(R^{2}\right)$ between the MS signal and the concentration of 5-metC in a range of $0.5-5 \mu \mathrm{M}$ or $\mathrm{dU}$ in a range of $10-100 \mu \mathrm{M}$ was 0.9954 and 0.9999 , respectively. The coefficient of variation was 16.94 and $14.77 \%$, respectively. The applicability of this assay is demonstrated by detection of a decrease in 5 -metC $\%$ and elevation of dU/thymidylate (dT) into genomic DNA extracted from the HepG2 cell line grown in a folate-depleted me-
\end{abstract}

dium. Conclusion: Our results confirm that the HPLC/ESI-MS method reported earlier for measuring 5-metC allows measurement of uracil misincorporation into DNA.

Copyright $\odot 2009$ S. Karger AG, Basel

\section{Introduction}

Folate deficiency presents a significant health problem $[1,2]$. Evidence from studies indicates that inadequate folate intake enhances the risk of cancer because folate has critical functions in biological methylation reactions such as DNA-cytosine methylation, and in DNA synthesis or repair $[3,4]$. The methylation of DNA is a fundamental mechanism for epigenetic control of gene expression and the maintenance of genomic integrity. The substrate for DNA methylation is S-adenosylmethionine, which is a product of carbon metabolism and linked to diet through folate status, but also via other naturally occurring dietary chemicals such as choline. Folate is also fundamental for the synthesis of purines and a pyrimidine nucleoside (thymidine). Thymidylate synthase catalyzes the conversion of uridylate or deoxyuridine monophosphate to thymidylate (dT) or deoxythymidine monophosphate. Low folate reduces dT synthase-mediated methylation of deoxyuridylate (dU) to dT [5]. This results in a higher dU/dT ratio, an increase in uracil misincorporation into DNA,

\section{KARGER}

Fax +4161306 1234

E-Mail karger@karger.ch

www.karger.com (c) 2009 S. Karger AG, Basel

1011-7571/09/0182-0081\$26.00/0

Accessible online at:

www.karger.com/mpp
Dr. Abalo Chango

Assoc. Prof. of Nutritional Genomics, Head of UPSP 2007.05.137, EGEAL

Institut Polytechnique LaSalle de Beauvais, 19, rue Pierre Waguet

FR-60026 Beauvais Cedex (France)

Fax +33 3440625 26, E-Mail abalo.chango@isab.fr 
inefficient DNA repair and an increase in chromosomal segregation and breakage $[3,6,7]$.

DNA hypomethylation and uracil misincorporation/ repair are not exclusive mechanisms and both could be important in diagnostics. Since both aspects of DNA modification are strongly associated with folate status and carcinogenesis, development of an efficient method for measuring simultaneously DNA-cytosine methylation and DNA-uracil is of great interest. Several methods have been developed to determine changes in global DNA methylation [8] or in DNA fragments [9] and in uracil misincorporation into DNA. However, none of the existing procedures permits the simultaneous assessment of both 5methylcytosine (5-metC) and 2'-deoxyuridine monophosphate (dU) into DNA in one assay. Here, an existing method for 5-metC assay was optimized to allow simultaneous assay of both 5-metC and dU. The method was used successfully in this study to determine both parameters in HepG2 cell lines that were exposed to in vitro folate deficiency. It may be suggested as an efficient approach for evaluation of DNA instability in medical investigations.

\section{Materials and Methods}

\section{Cell Culture}

Confluent HepG2 cells (ECACC, No. 85011430) at 60-80\% routinely grown in MEM, supplemented with $20 \%$ fetal bovine serum at $37^{\circ} \mathrm{C}$ in a $5 \% \mathrm{CO}_{2}$-humidified incubator, were first replated into $25-\mathrm{cm}^{2}$ culture flasks $\left(4.5 \times 10^{5}\right.$ cells/flask $)$ in complete MEM (ECM, Invitrogen, Cergy Pontoise, France) for $24 \mathrm{~h}$. After another $24 \mathrm{~h}$, growth medium was removed and the adhering cells were gently washed in phosphate-buffered saline. One flask was immediately used for DNA extraction and was referred to as T0. In all other flasks cells were grown in either control experimental medium, i.e. ECM, or in a folic acid-depleted medium (FDM). Media were added such that the cells were maintained under these conditions for the incubation period: $24 \mathrm{~h}$ (T24), $48 \mathrm{~h}$ (T48), or $72 \mathrm{~h}$ (T72). All media were supplemented with $4 \%$ of dialyzed fetal bovine serum and 1\% L-glutamine.

\section{DNA Extraction and Treatment}

Genomic DNA was isolated from cells using the Trizol ${ }^{\circledR}$ reagent (Invitrogen), following the manufacturer's instruction, and frozen at $-20^{\circ} \mathrm{C}$ until analysis. To avoid any RNA contamination, 1- $\mu$ g DNA samples were first treated with both RNAse A (SigmaAldrich R4642, Lyon, France) and RNAse T1 (Ozymes EN0101, St. Quentin-en-Yvelines, France) to a final concentration of 10 units $/ \mathrm{ml}$ at $37^{\circ} \mathrm{C}$ for $1 \mathrm{~h}$ [10]. This RNA removal step is of high importance because it avoids the quantification of uracil and other nucleosides present in RNA. DNA cleanup was conducted using the QIAamp DNA Micro kit (Qiagen, Courtabœuf, France). Enzymic hydrolysis of DNA was performed as follows: DNA was first denatured by heating at $100^{\circ} \mathrm{C}$ for $3 \mathrm{~min}$ and subsequently chilled on ice. One-tenth volume of $0.1 \mathrm{M}$ ammonium acetate (Sig-
ma-Aldrich, Lyon, France) and 2 units of nuclease P1 (Sigma-Aldrich, N8630) were added. The mixture was then incubated at $45^{\circ} \mathrm{C}$ for $2 \mathrm{~h}$. One-tenth volume of $1 \mathrm{M}$ ammonium bicarbonate (Sigma-Aldrich) and 0.002 units of venom phosphodiesterase I (Sigma-Aldrich, P3134) were subsequently added to the solution. Incubation was continued for additional $2 \mathrm{~h}$ at $37^{\circ} \mathrm{C}$. Thereafter, the mixture was incubated for $1 \mathrm{~h}$ at $37^{\circ} \mathrm{C}$ with 0.5 units alkaline phosphatase (Sigma-Aldrich, P4978).

\section{5-metC and Uracil Assay}

Twenty microliters of hydrolyzed DNA solution was used for chromatographic analysis. Mixtures of the standard bases $2^{\prime}$-deoxyadenosine (dA), 2'-deoxyguanosine (dG), dT, 2'-deoxycytidine $(\mathrm{dC})$, and $\mathrm{dU}$ at $100 \mu \mathrm{M}$ and $5-$ metC at $5 \mu \mathrm{M}$ (Sigma-Aldrich) were used as standards to prepare the calibration curve. Nucleoside quantitation was monitored with a reverse phase-high performance liquid chromatography (RP-HPLC) coupled to a Finnigan LTQ mass spectrometer (Thermo Fisher Scientific, Courtabœuf, France). Chromatography was performed using a $2.0 \times$ $150-\mathrm{mm}$ Gemini C18 column (5 $\mu \mathrm{m}$ particle size, Phenomenex, Le Pecq, France). Nucleosides were eluted by $7 \mathrm{~mm}$ ammonium acetate $\mathrm{pH} 6.7 /$ methanol $95 / 5(\mathrm{v} / \mathrm{v})$ at a flow rate of $0.3 \mathrm{ml} / \mathrm{min}$. Electrospray source condition was spray voltage $5 \mathrm{kV}$. The mass spectrometer was operated at a capillary voltage of $34 \mathrm{~V}$ and capillary temperature of $330^{\circ} \mathrm{C}$. The ion trap mass spectrometer was set in positive ion detection mode and gated to detect ion species with an $\mathrm{m} / \mathrm{z}$ ratio of $112,113,126,127,136$ and 152 for $\mathrm{dC}, \mathrm{dU}$, 5-metC, dG, dT and $\mathrm{dA}$, respectively.

\section{Statistics}

Statistical analyses were performed using StatView-5 (SAS, Cary, N.C., USA). Differences between means were determined by the Student $t$ test and ANOVA. Results are presented as means \pm SD. A p value less than 0.05 was considered statistically significant.

\section{Results}

Typical HPLC/MS chromatograms of standards and DNA digests are shown in figure 1 . The peaks eluted correspond to dC (at $2.8 \mathrm{~min}$ ), dU (at $4.2 \mathrm{~min}$ ), 5-metC (at $5.3 \mathrm{~min}$ ), dG (at $6.6 \mathrm{~min}$ ), dT (at $8.1 \mathrm{~min}$ ), and dA (at 15.6 min). We observed a peak eluted at 9.2 min corresponding to an unidentified compound. External standard curves obtained with the $\mathrm{dC}$ or $\mathrm{dU}$ for each assay were highly reproducible with no significant difference in slopes between the runs in three different assays. The linear correlation coefficients $\left(\mathrm{R}^{2}\right)$ between the MS signal and the concentration of 5-metC in a range of $0.5-5 \mu \mathrm{M}$ or $\mathrm{dU}$ in a range of $10-100 \mu \mathrm{M}$ were 0.9954 and 0.9999 , respectively. The coefficient of variation was 16.94 and $14.77 \%$, respectively. The relative percentages of 5-metC (\% of 5-metC vs. dC), and uracil misincorporation/[dT] ratio in the samples collected at $0,24,48$ and $72 \mathrm{~h}$ are shown in table 1 . Folate depletion decreased 5 -metC, and 
Fig. 1. HPLC/ESI-MS chromatograms of external standards (top) and a DNA digest sample (bottom). In the bottom panel, the peak eluted at 9 min $\left(^{*}\right)$ corresponds to an unidentified compound.

Table 1. Results of HPLC/ESI-MS analysis of 5-metC and $\mathrm{dU} / \mathrm{dT}$ ratio

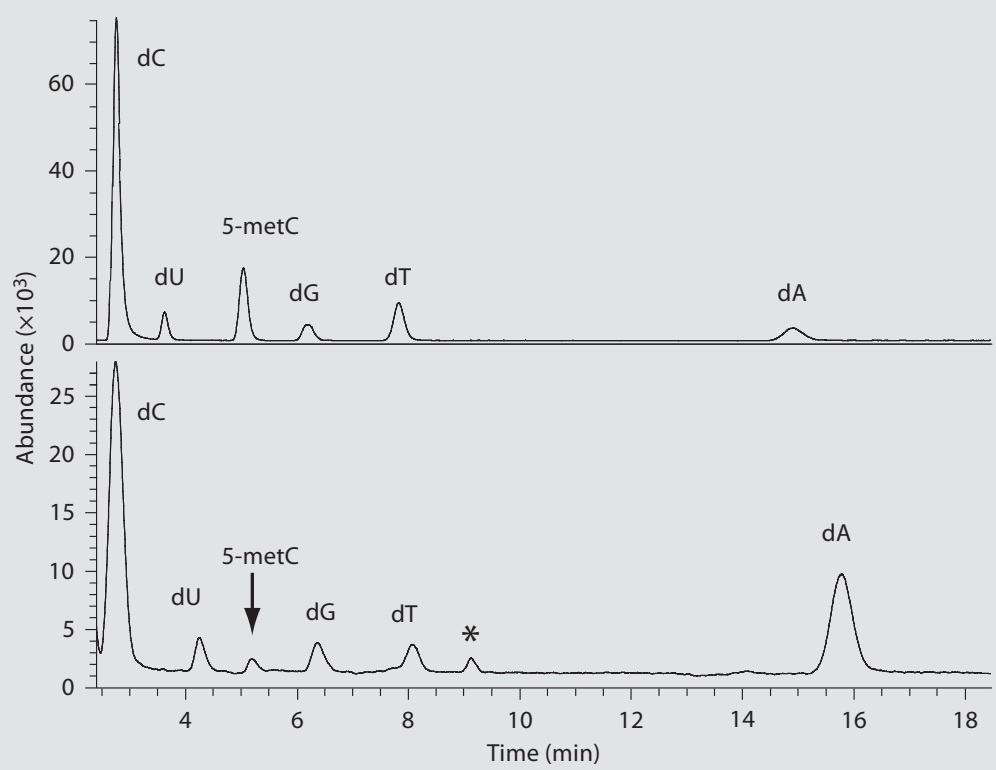

\begin{tabular}{|c|c|c|c|c|c|}
\hline \multirow{2}{*}{$\begin{array}{l}\text { Incubation } \\
\text { time }\end{array}$} & \multirow[t]{2}{*}{ Medium } & \multicolumn{2}{|l|}{ 5-metC, \% } & \multicolumn{2}{|l|}{$\mathrm{dU} / \mathrm{dT}$ ratio } \\
\hline & & $\begin{array}{l}{[5-\mathrm{metC} / \mathrm{dC}+} \\
5-\text { metC }] \times 100\end{array}$ & $\mathrm{p}$ & $\mathrm{dU} / \mathrm{dT}$ & $\mathrm{p}$ \\
\hline $0 \mathrm{~h}$ & & $6.01 \pm 0.04$ & & $0.022 \pm 0.002$ & \\
\hline $24 \mathrm{~h}$ & $\begin{array}{l}\text { ECM } \\
\text { FDM }\end{array}$ & $\begin{array}{l}6.62 \pm 0.02 \\
2.72 \pm 0.03\end{array}$ & 0.05 & $\begin{array}{l}0.024 \pm 0.002 \\
0.394 \pm 0.007\end{array}$ & 0.05 \\
\hline $48 \mathrm{~h}$ & $\begin{array}{l}\text { ECM } \\
\text { FDM }\end{array}$ & $\begin{array}{l}6.60 \pm 0.12 \\
2.42 \pm 0.01\end{array}$ & 0.05 & $\begin{array}{l}0.017 \pm 0.001 \\
0.303 \pm 0.005\end{array}$ & 0.05 \\
\hline $72 \mathrm{~h}$ & $\begin{array}{l}\text { ECM } \\
\text { FDM }\end{array}$ & $\begin{array}{l}7.03 \pm 0.12 \\
2.08 \pm 0.07\end{array}$ & 0.05 & $\begin{array}{l}0.022 \pm 0.002 \\
0.500 \pm 0.009\end{array}$ & 0.05 \\
\hline
\end{tabular}

Cells were grown in ECM or FDM. its value in FDM was about 2.4 times less than in ECM $(p<0.05)$. It was 2.7 and 3.4 times less after 48 and $72 \mathrm{~h}$, respectively $(\mathrm{p}<0.05)$. Inversely, folate depletion increased dU/dT about 16.4 times after $24 \mathrm{~h}(\mathrm{p}<0.05)$. The increase was 17.8 and 22.7 times higher in FDM than in ECM after 48 and $72 \mathrm{~h}$, respectively $(\mathrm{p}<0.05)$.

\section{Discussion}

In vitro moderate folate deficiency is associated with a decrease in DNA methylation and DNA instability measured as uracil misincorporation into DNA [11]. Using HPLC/electrospray ionization mass spectrometry
(ESI-MS), Friso et al. [10] reported a sensitive method for the measurement of small amounts $(1 \mu \mathrm{g})$ of methylated cytosine residues in genomic DNA. The method allowed separation and identification of the major DNA bases: $\mathrm{dA}, \mathrm{dG}, \mathrm{dT}, \mathrm{dC}$, and 5-metC. This method was used in the present study for measuring simultaneously 5-metC and dU. Removing RNA uracil by treating extracted DNA with RNAse A and RNAse T1 before analysis was an important step in this method, as $\mathrm{dU}$ can be provided by RNA. This may be the first attempt to quantify both 5-metC and dU simultaneously in DNA samples.

The method was applied to genomic DNA from the HepG2 cell line grown either in ECM or FDM. As shown in table 1, there was global hypomethylation of genomic 
DNA induced by the absence of folic acid in FDM. The 5 -metC $\%$ was $6.01 \pm 0.04$ at T0. It represented $2.72 \pm$ $0.03 \%$ at T24 in FDM. The results showed that the decrease in 5-metC after folate depletion was time-dependent. Meanwhile, we observed a significant increase of uracil residues in the same DNA sample. The increase in dU/dT was about 16.4, 17.8 and 22.7 times higher in FDM than in ECM after 24, 48, and $72 \mathrm{~h}$. These observations are in accordance with previous studies that used other methods [7, 11-13]. In the present study, the absolute amounts of 5-metC and dU determined in control cells at T0 were $1.24 \mathrm{ng} / \mu \mathrm{g}$ and $6.34 \mathrm{pg} / \mu \mathrm{g}$ of DNA, respectively. It is well known that both parameters are tissuespecific and can change according to the culture medium used or the individual subject concerned. This analysis may be a useful tool when used in conjunction with an initial, basic state of cells in culture, or a control group in a population study. In mammalian genomes 5 -metC represents $3-10 \%$ of cytosines [14]. For uracil also, a wide range of DNA-uracil levels $(0.2-129 \mathrm{pg} / \mu \mathrm{g})$ in human cells have been reported in the literature [12, 13, 15-17]. This wide range is probably accentuated by technical difficulties. A major complication in the analysis of uracil content in DNA is probably in situ deamination of cytosine residues [18]. Deamination turns a C-G pair into a
U-G mismatch and, unless repaired by a uracil-DNA glycosylase, can increase uracil content in DNA. Two major points need to be validated in the future for application of this method in medical investigation. The first is concerned with DNA-uracil concentrations in healthy human blood cells (or specific normal tissues) and the second with artefact in uracil content due to cytosine deamination. These issues need further investigation.

\section{Conclusion}

Our results confirmed that the HPLC/ESI-MS method reported earlier for measuring 5-metC allowed the measurement of uracil misincorporation into DNA. It may also be refined for evaluation of cytosine deamination. The method may be suggested as an efficient approach for the evaluation of DNA instability in folate deficiency.

\section{Acknowledgment}

The study was supported by a grant from the Comite de l'Oise de la Ligue Contre le Cancer, France.

\section{References}

1 Kim YI: Folate and cancer prevention: a new medical application of folate beyond hyperhomocysteinemia and neural tube defects. Nutr Rev 1999;57:314-321.

-2 Krishnaswamy K, Madhavan Nair K: Importance of folate in human nutrition. Br J Nutr 2001;85(suppl 2):S115-S124.

$\checkmark 3$ Blount BC, Ames BN: DNA damage in folate deficiency. Baillieres Clin Haematol 1995;8: 461-478.

$>4$ Krumdieck CL, Howard-Peebles PN: On the nature of folic-acid-sensitive fragile sites in human chromosomes: an hypothesis. Am J Med Genet 1983;16:23-28.

$\checkmark 5$ Matthews JH, Shiels S, Wickramasinghe SN: The effects of folate deficiency on thymidylate synthetase activity, deoxyuridine suppression, cell size and doubling time in a cultured human myeloid cell line. Eur J Haematol 1990;45:43-47.

-6 Herbert V: The role of vitamin B12 and folate in carcinogenesis. Adv Exp Med Biol 1986; 206:293-311.

7 James SJ, Pogribny IP, Pogribna M, Miller BJ, Jernigan S, Melnyk S: Mechanisms of DNA damage, DNA hypomethylation, and tumor progression in the folate/methyl-deficient rat model of hepatocarcinogenesis. J Nutr 2003;133:3740S-3747S.
8 Fraga MF, Esteller M: DNA methylation: a profile of methods and applications. Biotechniques 2002;33:632, 634, 636-649.

$\checkmark 9$ Chango A, Abdennebi-Najar L, Tessier F, Ferre S, Do S, Gueant JL, et al: Quantitative methylation-sensitive arbitrarily primed PCR method to determine differential genomic DNA methylation in Down syndrome. Biochem Biophys Res Commun 2006;349:492-496.

10 Friso S, Choi SW, Dolnikowski GG, Selhub J: A method to assess genomic DNA methylation using high-performance liquid chromatography/electrospray ionization mass spectrometry. Anal Chem 2002;74:4526-4531.

11 Fenech M: The role of folic acid and vitamin B12 in genomic stability of human cells. Mutat Res 2001;475:57-67.

12 Ren J, Ulvik A, Refsum H, Ueland PM: Uracil in human DNA from subjects with normal and impaired folate status as determined by high-performance liquid chromatographytandem mass spectrometry. Anal Chem 2002;74:295-299.

13 Blount BC, Mack MM, Wehr CM, MacGregor JT, Hiatt RA, Wang G, et al: Folate deficiency causes uracil misincorporation into human DNA and chromosome breakage: implications for cancer and neuronal damage. Proc Natl Acad Sci USA 1997;94: 3290-3295.

14 Frostesjo L, Holm I, Grahn B, Page AW, Bestor TH, Heby O: Interference with DNA methyltransferase activity and genome methylation during F9 teratocarcinoma stem cell differentiation induced by polyamine depletion. J Biol Chem 1997;272: 4359-4366.

15 Mashiyama ST, Courtemanche C, ElsonSchwab I, Crott J, Lee BL, Ong CN, et al: Uracil in DNA, determined by an improved assay, is increased when deoxynucleosides are added to folate-deficient cultured human lymphocytes. Anal Biochem 2004;330:5869.

-16 Crott JW, Mashiyama ST, Ames BN, Fenech MF: Methylenetetrahydrofolate reductase C677T polymorphism does not alter folic acid deficiency-induced uracil incorporation into primary human lymphocyte DNA in vitro. Carcinogenesis 2001;22:1019-1025.

17 Ramsahoye BH, Burnett AK, Taylor C: Nucleic acid composition of bone marrow mononuclear cells in cobalamin deficiency. Blood 1996;87:2065-2070.

18 Sousa MM, Krokan HE, Slupphaug G: DNAuracil and human pathology. Mol Aspects Med 2007;28:276-306. 